\title{
Clearing your mind of work-related stress through moderate-to-vigorous and leisure-time physical activity: What 'dose' it takes?
}

\author{
Jean-Philippe Lachance ${ }^{1,2}$, Marc Corbière ${ }^{2,3}$, Gabriel Hains-Monfette ${ }^{1,2}$ and Paquito Bernard ${ }^{2,4}$ \\ ${ }^{1}$ Health and Society Institute, Université du Québec à Montréal, Montreal, Canada \\ ${ }^{2}$ Research Center of the Montreal Mental Health University Institute, Montreal, Canada \\ ${ }^{3}$ Department of Education and Pedagogy, Université du Québec à Montréal, Montreal, Canada \\ ${ }^{4}$ Department of Physical Activity Sciences, Université du Québec à Montréal, Montreal, Canada
}

Word count: 3187

\section{Author Note}

Data access and analysis were sponsored by the Quebec inter-University Centre for Social Statistics (QICSS). We have no conflicts of interest to disclose.

Correspondence concerning this article should be addressed to Jean-Philippe Lachance, Institut universitaire en santé mentale de Montréal, 7401 Hochelaga Street, Montréal, Québec, Canada, H1N 3M5, Pavillon Riel RI-226-49, Email: lachance.jean-philippe@courrier.uqam.ca 
medRxiv preprint doi: https://doi.org/10.1101/2020.05.11.20097931; this version posted May 14, 2020. The copyright holder for this preprint (which was not certified by peer review) is the author/funder, who has granted medRxiv a license to display the preprint in perpetuity.

WORK-RELATED STRESS AND PHYSICAL ACTIVITY

\begin{abstract}
Background. Work is reported as one of the main sources of psychological stress. Because of its role in the onset of burnout and impact on economic and health systems, work-related stress (WS) has become an issue of much concern. Among modifiable factors capable of reducing WS, two categories of physical activity (PA), namely leisure-time and moderate-to-vigorous physical activity (LTPA and MVPA), show promising evidence. Previous findings suggest that LTPA and MVPA allow adults to experience psychological detachment from job demands and restore their depleted resources at work. However, the optimal independent doses of LTPA and MVPA associated with a lower WS level has not yet been established. Methods. The aim of this study was therefore to address this gap using a cross-sectional, nationally representative sample of 4200 Canadian workers. MVPA was measured through accelerometry and a self-reported assessment was conducted to collect data on WS and LTPA. Results. Generalized additive models indicated that one hour a day on average spent doing a LTPA of 8.5 METshour was associated with the highest benefits on WS ( $<0.001$, Adjusted R2 $=0.04$ ) while the optimal average daily dose of MVPA was around 90 minutes ( $p<0.001$, Adjusted R2 =0.04). Noteworthy, first signs of WS reduction appear long before optimum is reached (e.g. 30 minutes of MVPA), stressing the relevance of merely doing an LTPA/MVPA regardless of the dose. Conclusion. Findings offer practical recommendations for public health policies on the optimal doses of MVPA/LTPA associated with decreased WS.
\end{abstract}

Keywords: work stress, leisure activity, physical activity, nonlinear relationship, generalized additive model, Canadian workers 
medRxiv preprint doi: https://doi.org/10.1101/2020.05.11.20097931; this version posted May 14, 2020. The copyright holder for this preprint (which was not certified by peer review) is the author/funder, who has granted medRxiv a license to display the preprint in perpetuity. All rights reserved. No reuse allowed without permission.

\section{What is already known on this subject?}

- Work-related stress (WS) is one of the major sources of psychological stress and creates fertile ground for the onset and aggravation of physiological and psychiatric conditions.

- Leisure-time and moderate-to-vigorous physical activity (LTPA and MVPA) are known to exert a stress-buffering effect, yet their respective dose-response relationship with WS remains unknown.

\section{What this study adds?}

- This is the first study that has employed a nationally representative sample to identify the optimal amount of LTPA and MVPA associated with lower WS levels.

- $\quad$ One hour a day on average spent doing an LTPA of 8.5 METs-hour is associated with the highest benefits, the optimal average daily dose of MVPA is around 90 minutes, and first signs of reduction in WS appear long before optimum are reached, stressing the relevance of merely practising a LTPA/MVPA regardless of the dose.

\section{BACKGROUND}

Psychological stress has been dubbed "the health epidemic of the 21 st century" by the World Health Organization. ${ }^{1}$ Psychological stress is classically defined as "a particular relationship between the person and the environment that is appraised by the person as taxing or exceeding his or her resources and endangering his or her well-being". ${ }^{2}$ While acute punctual stress is unavoidable and adaptive, repeated exposure to perceived threat that results in a significant release of stress hormones may be damaging. ${ }^{3}$ As pioneer studies on stress have pointed out, no organism can be maintained continuously in a state of alarm without entering a stage of exhaustion. ${ }^{4}$ Chronic stress is indeed prospectively associated with the onset and aggravation of metabolic syndrome, ${ }^{5}$ neurodegenerative diseases ${ }^{6}$ as well as psychiatric conditions such as major depression. ${ }^{7}$

Work-related stress (WS) is one of the major sources of psychological stress. ${ }^{8,9}$ In Canada, over one in four workers describe their lives as highly stressful and work is cited as the main source of stress for $60 \%$ of those. ${ }^{8}$ In absolute numbers, this prevalence represented in 2010 three millions of people across the country. When unsuccessfully managed at an individual and organizational levels, WS can 
medRxiv preprint doi: https://doi.org/10.1101/2020.05.11.20097931; this version posted May 14, 2020. The copyright holder for this preprint (which was not certified by peer review) is the author/funder, who has granted medRxiv a license to display the preprint in perpetuity. All rights reserved. No reuse allowed without permission.

become fertile ground for burnout, ${ }^{10}$ a costly occupational-related syndrome characterized by feelings of energy depletion or exhaustion, increased mental distance from one's job, feelings of negativism or cynicism related to one's job and reduced professional efficacy. ${ }^{11}$

Over the recent decades, life habits such as physical activity (PA) have been receiving much attention from scientists in search of modifiable protective factors against WS. There is scientific evidence showing PA is negatively associated with WS and other health outcomes related with WS such as depression. ${ }^{12}$ One explanation for that protective effect lies in the idea that PA consists of a recovery activity allowing the person to experience psychological detachment from the job demands and restore their depleted resources at work. ${ }^{13}$ It is also well established that the neurophysiological correlates of PA such as the production of endorphins improve mood. ${ }^{14}$

In line with these hypotheses, a growing body of evidence suggests that leisure-time PA (LTPA) as well as moderate-to-vigorous PA (MVPA) are particularly protective against WS. ${ }^{15,16}$ Indeed, some PA modalities such as the domain (occupational, transportation, housework, leisure time) and the intensity seem to play a moderating role in the relationship between PA and mental health. Two recent meta-

analyses ${ }^{17,18}$ have shown that LTPA, contrary to other PA domains such as occupational PA or household PA, has been found to be positively associated with mental health outcomes including WS. Regarding the intensity of PA, studies suggest that daily time spent in MVPA could be effective in improving mental health-related outcomes, ${ }^{15,16}$ and eventually reducing WS.

\section{Purpose of the Present Study}

To date, however, the shape of the association with WS, both for LTPA and MVPA, have not been examined so far in a national representative sample. Without any knowledge of the dose-response relationship (e.g. the dose producing the optimal response), it remains difficult to optimize appropriate LTPA and MVPA interventions to ensure the strongest possible decrease in WS at a population level. By bridging the gap in the literature on PA and WS, the aim of this study was to identify the respective doseresponse associations of LTPA and MVPA with WS among a high-quality representative national sample of workers. 
medRxiv preprint doi: https://doi.org/10.1101/2020.05.11.20097931; this version posted May 14, 2020. The copyright holder for this preprint (which was not certified by peer review) is the author/funder, who has granted medRxiv a license to display the preprint in perpetuity.

WORK-RELATED STRESS AND PHYSICAL ACTIVITY

\section{METHODS}

\section{Data sources and dataset description}

Data were obtained from the combined cycles 1 and 2 (2007 to 2009 and 2009 to 2011) of the Canadian Health Measures Survey (CHMS), ${ }^{19}$ a nationally representative cross-sectional survey of Canadians led by Statistics Canada in partnership with Health Canada and the Public Health Agency of Canada. Data were collected in two stages. First, sociodemographic and general health information were collected during an interview at the participants' home. Then, weight and height measurements were collected during a subsequent visit to a mobile clinic. The CHMS cycles 1 and 2 employ a stratified sampling protocol to recruit a representative sample of respondents aged from 6 to 79 years old living in privately occupied dwellings in five provinces (New Brunswick, Quebec, Ontario, Alberta, British Columbia) covering approximately $96 \%$ of the Canadian population, east to west, with larger and smaller population densities. People living in one of the three territories (Northwest Territories, Nunavut, and Yukon), Indian Reserves or Crown lands, residents of institutions, full-time members of the Canadian Forces and residents of certain remote regions were excluded for feasibility reasons. This survey was approved by the Health Canada's Research Ethics Board and all respondents provided written informed consent. Detailed information on background, methodology and ethical issues of the CHMS are available elsewhere. $^{19,20}$

In our study, we included Canadians aged 18 to 65 years who reported being employed in the past 12 months with complete data for self-perceived chronic work-related stress (WS), physical activity (PA) data from accelerometer and self-reported leisure-time physical activity (LTPA). Pregnant women and people with functional limitations were not included in analyses.

\section{Variables}

Outcome: Self-perceived work-related stress (WS). Self-perceived chronic work-related stress was assessed using this five-point Likert scale item: "Would you say that most days at work in the past 12 months were: Not at all stressful (coded as '1'), Not very stressful ('2'), A bit stressful ('3'), Quite a bit 
medRxiv preprint doi: https://doi.org/10.1101/2020.05.11.20097931; this version posted May 14, 2020. The copyright holder for this preprint (which was not certified by peer review) is the author/funder, who has granted medRxiv a license to display the preprint in perpetuity. All rights reserved. No reuse allowed without permission.

WORK-RELATED STRESS AND PHYSICAL ACTIVITY

stressful ('4'), Extremely stressful ('5')?’ Firstly introduced within the Canadian Community Health Survey, this item is widely used to evaluate the level of self-perceived WS in the Canadian population. ${ }^{21}$

Exposure 1: Device-assessed Moderate-to-Vigorous Physical Activity (MVPA). Upon completion of a mobile examination center visit, participants were asked to wear an Actical accelerometer (PhillipsRespironics, 17 grams, omnidirectional accelerometer) over their right hip on an elasticized belt during their waking hours for 7 consecutive days. The Actical is a valid and reliable instrument to measure PA in adults. ${ }^{22}$ The accelerometers started to collect data the day after the mobile examination centre appointment. The monitors were then posted to Statistics Canada. The data were validated by research assistants to determine if they were still within the manufacturer's calibration specifications. The Actical measures and records time-stamped acceleration in all directions, thereby indicating the intensity of physical activity. The digitized values are summed over an interval of one minute. Accelerometer data were in a count value per minute (cpm) and also into steps accumulated per minute. ${ }^{23}$ All data are blind to respondents while they are wearing the device. Consistent with common analytical procedures for accelerometry, a valid day was defined as 10 or more hours of wear time and respondents with 4 or more valid days were retained for analyses. ${ }^{24}$ Accelerometer data were not included in the analyses if a participant had extreme counts (i.e. $>20000 \mathrm{cpm}$ ). ${ }^{24}$ The number of minutes per day spent in MVPA was categorized using validated cut-offs of cpm for adults, which corresponds to $\geq 1535 \mathrm{cpm}^{23}$ The average minutes per day of MVPA was used in analyses.

\section{Exposure 2: Daily energy expenditure in Leisure-Time Physical Activities (LTPA). As a} composite variable, LTPA energy expenditure was determined from information about the frequency and duration of respondents' participation in a variety of physical activities during leisure time by the respondent in the past three months. For each reported activity (a total of 21 leisure activities such as gardening, soccer, swimming, as well as all other non-listed choices of leisure PA - see supplementary material), energy expenditure was calculated by multiplying the number of times a respondent engaged in the activity over a 12-month period (a 3-month recall period multiplied by 4) by the average duration in minutes and the energy cost of the activity (the metabolic equivalent - MET, i.e. kilocalories expended 
medRxiv preprint doi: https://doi.org/10.1101/2020.05.11.20097931; this version posted May 14, 2020. The copyright holder for this preprint (which was not certified by peer review) is the author/funder, who has granted medRxiv a license to display the preprint in perpetuity. All rights reserved. No reuse allowed without permission.

WORK-RELATED STRESS AND PHYSICAL ACTIVITY

per kilogram of weight per hour of activity). For each LTPA, the MET is a value of metabolic energy cost expressed as a multiple of the resting metabolic rate. For example, an activity of 4 METs requires four times the amount of energy the body needs when it is at rest. To calculate the daily energy expenditure for an activity, the yearly estimate was divided by 365 . This calculation was repeated for all leisure-time activities reported, and the resulting estimates were summed to yield average daily energy expenditure. MET values tend to be expressed in three intensity levels (i.e. low, medium, high). Since the CHMS questions did not ask the respondent to specify the intensity level of their activities, the MET values adopted corresponded to the low intensity value of each activity. This approach is adopted from the Canadian Fitness and Lifestyle Research Institute because individuals tend to overestimate the intensity, frequency and duration of their activities (Statistics Canada, 2007). The formula used to derive the energy expenditure in LTPA was:

Energy expenditure in LTPA $=(\mathrm{N} * \mathrm{D} *$ MET value $) / 365$

Where:

$\mathrm{N}=$ the number of times a respondent engaged in an activity over a 12-month period

$\mathrm{D}=$ the average duration in hours of the activity

MET value $=$ the energy cost of the activity expressed as kilocalories expended per kilogram of body weight per hour of activity ( $\mathrm{kcal} / \mathrm{kg}$ per hour)/365 (to convert yearly data into daily data, namely METs-hour per day)

Covariates. Sociodemographic covariates included age, sex $(\mathrm{m} / \mathrm{w})$, daily smoking (cotinine blood level in $\mathrm{ng} / \mathrm{mL}$ ), household income (ranged from < 15000 to $100000 \$+$ ), marital status and education levels (ranged from < high school to university). Accelerometer wear time (daily minutes) and season of accelerometer assessment were also computed and included in analyses. Body mass index was computed by measuring an individual's weight and height during mobile clinic visit. All these covariables are commonly related to PA in adults. ${ }^{25}$ Constructs potentially related to WS such as self-perceived general stress and self-perceived mental health, both measured on a five-point Likert scale, were also included in the models. 
medRxiv preprint doi: https://doi.org/10.1101/2020.05.11.20097931; this version posted May 14, 2020. The copyright holder for this preprint (which was not certified by peer review) is the author/funder, who has granted medRxiv a license to display the preprint in perpetuity. All rights reserved. No reuse allowed without permission.

WORK-RELATED STRESS AND PHYSICAL ACTIVITY

\section{Statistical analysis}

Generalized additive models (GAMs) were used to examine the shape of the association between WS and MVPA, and then between WS and LTPA. The GAM is an extension of the generalized linear model in that one or more predictors may be specified using a smooth function. ${ }^{26}$ GAM is a nonparametric model that allows nonlinear relationships to be modelized without specifying the functional form a priori. The GAM is estimated using a penalized maximum likelihood procedure usually iteratively reweighted least squares. Predictions from GAM were plotted with $95 \%$ confidence intervals. To account for the complex, multistage probability sampling design, the weights provided by the CHMS were used in the analyses (i.e. activity monitor subsample weights combining cycles 1 and 2). All analyses were performed using survey packages ${ }^{27}$ in $\mathrm{R}$ version 3.3 .

\section{RESULTS}

\section{Sample characteristics}

Accelerometer data from the two cycles were available from 4200 participants (rounded to the nearest 10 as per Statistics Canada confidentiality requirements) and were included in the current study. The mean scores (1 to 5, from better to worst) of participants on self-perceived mental health, selfperceived general stress and self-perceived work-related stress were respectively 1.97 (Standard error $[\mathrm{SE}]=0.32, \mathrm{Mdn}=2.01), 2.78(\mathrm{SE}=0.49, \mathrm{Mdn}=2.70)$ and $2.98(\mathrm{SE}=0.49, \mathrm{Mdn}=2.90)$. Descriptive analysis also revealed a normal distribution both for general and work-related stress but a right-skewed one for the mental health scale. We observed that $31 \%$ report a high level of perceived work-related stress $(4=25 \% ; 5=6 \%)$ versus $20 \%(4=17 \% ; 5=3 \%)$ and $5 \%(4=1 \% ; 5=1 \%)$ concerning perceived general stress and mental health, respectively. The mean age was 44 years $(\mathrm{SE}=0.13)$ and $50.3 \%$ were women. Two thirds of the sample was in a relationship. On average, participants spent $21.3(\mathrm{SE}=0.4$, Mdn = 15.4) minutes per day of MVPA. Data from 14 univariate outliers were excluded because of extreme accelerometer data. Weighted characteristics of the study population are summarized in Table 1.

Table 1. Weighted characteristics of the study population (in millions) from cycles 
medRxiv preprint doi: https://doi.org/10.1101/2020.05.11.20097931; this version posted May 14, 2020. The copyright holder for this preprint (which was not certified by peer review) is the author/funder, who has granted medRxiv a license to display the preprint in perpetuity. All rights reserved. No reuse allowed without permission.

WORK-RELATED STRESS AND PHYSICAL ACTIVITY

1 and 2 of the Canadian Health Measures Survey (CHMS)

Age

$\mathrm{N}(\%)$ or Mean $\pm \mathrm{SE}$

Sex

Male

$12303047(49.82)$

Female

$12391325(50.18)$

Cotinine level (ng/mL)

$246.95 \pm 18.054$

Education \%

Less than high school diploma

$2465066(9.98)$

High school or work school

$7924541(32.09)$

College or university

$7209172(29.19)$

Not stated

$7095594(28.73)$

Household incomes (Canadian dollars)

$<20 \mathrm{k}$

$1665713(6.75)$

$20-<40 k$

$4320186(17.49)$

$40-<60 \mathrm{k}$

$4264498(17.27)$

$60-<80 \mathrm{k}$

$4048150(16.39)$

$80-<100 \mathrm{k}$

3231493 (13.09)

$>=100 \mathrm{k}$

$7164333(29.01)$

Marital status

Alone

$8570418(34.71)$

In a relationship

$16123955(65.29)$

Body mass index $(\mathrm{kg} / \mathrm{m} 2)$

$26.39 \pm 0.19$

Leisure-time physical activity LTPA (METs-hour/day)

$1.84 \pm 0.0562$

Moderate-to-vigorous physical activity MVPA (min/day)

$20.46 \pm 0.76$

Total volume of PA (counts/day)

$190.47 \pm 2.86$

Wear time of accelerometer (hours/day)

$13.73 \pm 0.05$

Seasons of assessment 
medRxiv preprint doi: https://doi.org/10.1101/2020.05.11.20097931; this version posted May 14, 2020. The copyright holder for this preprint (which was not certified by peer review) is the author/funder, who has granted medRxiv a license to display the preprint in perpetuity. All rights reserved. No reuse allowed without permission.

Autumn

Spring

Summer

Winter

Self-perceived mental health

Excellent

Very good

Good

Fair

Poor

Self-perceived general stress

Not at all stressful

Not very stressful

A bit stressful

Quite a bit stressful

Extremely stressful

Self-perceived work-related stress (WS)

Not at all stressful

Not very stressful

A bit stressful

Quite a bit stressful

Extremely stressful

Self-perceived health

Excellent, very good or good

Fair or poor
$8414385(34,07)$

$5491546(22,24)$

$4994525(20,23)$

$5793916(23,46)$

$1.97 \pm 0.32$

8462723 (34.52)

$9682090(39.49)$

5396853 (22.01)

973154 (3.97)

179553 (0.73)

$2.78 \pm 0.49$

2363075 (9.57)

6545954 (26.51)

10764333 (43.59)

4320187 (17.49)

700824 (2.84)

$2,98 \pm 0.49$

2212523 (8.96)

$4855196(19.66)$

10153007 (41.11)

6064663 (24.56)

1408983 (5.71)

$22088798(89.45)$

$2605574(10.55)$

\section{Shapes of association between exposures and outcomes}


medRxiv preprint doi: https://doi.org/10.1101/2020.05.11.20097931; this version posted May 14, 2020. The copyright holder for this preprint (which was not certified by peer review) is the author/funder, who has granted medRxiv a license to display the preprint in perpetuity. All rights reserved. No reuse allowed without permission.

WORK-RELATED STRESS AND PHYSICAL ACTIVITY

Figure 1 presents GAM results from adjusted models of WS as a respective function of MVPA and LTPA. The lines show the smoothed function from GAM for the two predictors and the dotted lines indicates the $95 \%$ confidence interval. Models including LTPA as the main predictor are also adjusted for MVPA since the Pearson correlation between the two measures is only of .32. Both LTPA and MVPA were significantly associated with self-perceived WS. A visual examination of the plots indicated nonlinear associations between both PA modalities and self-perceived WS.

MVPA and WS. A significant curvilinear relationship between MVPA and WS ( $\mathrm{p}<0.001$, Adjusted R2 = 0.04) with an optimal duration of 90 minutes/day (1 hour 30 minutes) was found, decreasing WS by at least 0.5 and at best 1.0 scale point (respectively top and bottom of the confidence interval) compared with an absence of MVPA.

LTPA and WS. Concerning LTPA, a significant association with WS ( $p<0.001$, Adjusted R2 = 0.04) was observed with a more complex shape. The graph shows a bumpy fluctuation pattern until a drop at $8.5 \mathrm{MET} / \mathrm{day}$, which means that an hour per day spent doing a leisure-time physical activity of 8.5 METs-hour is associated with the lowest WS level.

Insert Figure 1 about here (the title and the legend are at the end of the manuscript)

\section{DISCUSSION}

\section{Key findings}

Based on a nationally representative sample of workers $(n=4200)$, the aim of this study was to characterize the dose-response relationship between WS and two categories of physical activity, namely LTPA and MVPA.

Almost one third of our sample reported a high level of WS. Interestingly, there are many more people who are highly stressed by their work (WS, $31 \%$ of the sample) than by life in general (general stress, 20\%), underscoring the importance of addressing this source of stress in particular. With respect to the dose-response analysis, significant results show that the daily optimal levels for reducing WS seem to be around 90 minutes for MVPA and 8.5 METs-hour in daily energy expenditure for LTPA, even after controlling for sociodemographic and psychosocial variables that are known to be related to WS (e.g. 
medRxiv preprint doi: https://doi.org/10.1101/2020.05.11.20097931; this version posted May 14, 2020. The copyright holder for this preprint (which was not certified by peer review) is the author/funder, who has granted medRxiv a license to display the preprint in perpetuity. All rights reserved. No reuse allowed without permission.

WORK-RELATED STRESS AND PHYSICAL ACTIVITY

general stress). As a guide, MVPA ranges from moderate-intensity activities (3-6 METs), such as brisk walking, to vigorous-intensity activities (> 6 METs), such as carrying heavy loads or shovelling sand. LTPA worth 8.5 METs include, for example, backpacking, bicycling (25 km/h), handball, jogging (9 $\mathrm{km} / \mathrm{h})$ or swimming $(3 \mathrm{~km} / \mathrm{h})^{28,29}$

Should be remembered that optimal doses of MVPA and LTPA do not necessarily represent actual daily values, but rather a mean (calculated over a one-week accelerometer monitoring period for MVPA and a three-month recall period for LTPA). It follows that different distributions of PA frequencies (e.g. more PA during the weekend and less during the weekday) could be just as beneficial in reducing WS. Interestingly, lower PA doses (see figure 1) may also provide benefit albeit to a lesser extent. Indeed, compared to a physically inactive person, engaging in 30 minutes of MVPA a day is associated with reduction in WS, which is slightly more than the World Health Organization recommendations of 150 minutes of MVPA throughout the week $\left(\approx 20\right.$ minutes a day) ${ }^{30}$

Regarding LTPA, although its bumpy dose-response relationship with WS is relatively difficult to interpret, first signs of reduction in WS seem to appear from the moment the METs-hour exceeds zero, stressing the relevance of merely practising a LTPA, regardless of the energy expenditure. This is in line with previous studies which have shown that people who engaged in more PA reported lower WS and fewer burnout symptoms, ${ }^{12,18}$ yet without having established a dose-response relationship.

Taken together, these findings align with the tenet that getting some PA is better than none. In this respect, a growing body of literature indicates that even small increases of daily MVPA well below the optimum are nevertheless positively associated with mental health, ${ }^{31,32}$ although they did not measure WS.

\section{Strengths and limitations}

To the best of our knowledge, this is the first Canadian nationally representative study to investigate the specific dose-response relationship between WS and two relevant categories of PA, namely MVPA and LTPA ( $\mathrm{N}=4$ 200). This study has the merit of shedding light on the optimal levels of 
medRxiv preprint doi: https://doi.org/10.1101/2020.05.11.20097931; this version posted May 14, 2020. The copyright holder for this preprint (which was not certified by peer review) is the author/funder, who has granted medRxiv a license to display the preprint in perpetuity. All rights reserved. No reuse allowed without permission.

WORK-RELATED STRESS AND PHYSICAL ACTIVITY

MVPA/LTPA associated with a lower level of stress. Furthermore, those results are based on solid measure as MVPA was assessed using an Actical accelerometer.

The above findings notwithstanding, there are some limitations to this study that are worth noting. First, as it is often the case with large representative national surveys including several hundred questions, WS has been measured with a single-item scale that could be interpreted as equivocal. Thus, even though WS is nowadays negatively connoted and most often attributed to problematic psychosocial working conditions such as high job demands, ${ }^{33}$ it cannot be ruled out that WS could also have been interpreted by some respondents as "good stress" (eustress), which could explain the low effect size in the dose-response analysis. ${ }^{34}$ In fact, a stressor can also be perceived as a positive challenge if the individual thinks he has the abilities to overcome the stress-induced demands. ${ }^{35}$ In this case, the stressor may become a source of positive feelings ${ }^{36}$ and the neurophysiological response associated with eustress will be different from that triggered by distress. ${ }^{37}$ In light of this consideration, we strongly advocate that a single-item measure of WS would gain definitional clarity by simply giving the participant a unambiguous definition of "bad" work-related stress (work-related distress) in the instructions, such as "a particular relationship between the person and the environment that is appraised by the person as taxing or exceeding his or her resources and endangering his or her well-being".2

The other limitation lies in the cross-sectional design preventing from establishing the direction of causality for the association between PA and WS. However, this concern is mitigated by prospective cohort studies indicating a protective effect of PA against the emergence of mental disorders. ${ }^{38}$

\section{Conclusion}

Summing up the results, there are three things to keep in mind to help people clear their mind of WS: (1) one hour a day on average spent doing a LTPA of 8.5 METs-hour is associated with the highest benefits, (2) the optimal average daily dose of MVPA is around 90 minutes, and (3) first signs of reduction in WS appear long before optimum are reached (e.g. as soon as 30 minutes of MVPA), stressing the relevance of merely practising a LTPA/MVPA regardless of the dose. Drawn from a nationally representative sample, these findings are an important practical contribution, yet the pathways by which PA intervene in 
medRxiv preprint doi: https://doi.org/10.1101/2020.05.11.20097931; this version posted May 14, 2020. The copyright holder for this preprint (which was not certified by peer review) is the author/funder, who has granted medRxiv a license to display the preprint in perpetuity.

WORK-RELATED STRESS AND PHYSICAL ACTIVITY

reducing WS are far from being fully understood. In this vein, further research may want to investigate the specific mechanisms underlying the relationship between WS and MVPA/LTPA. Ultimately, in applied sciences, moving from a merely probabilistic relationship to a mechanistic explanation is essential to more targeted and effective interventions. ${ }^{39,40}$

\section{Figure 1}

Title: Dose-response relationships between WS-MVPA and WS-LTPA

Legend: WS = Work-related stress (Not at all stressful '1', Not very stressful '2', A bit stressful '3', Quite a bit stressful '4', Extremely stressful '5'), MVPA = Moderate and Vigorous Physical Activity, LTPA = Leisure-time physical activity. Lines represent smoothed means using generalized additive model, with short dashed lines representing 95\% CIs and long dashed lines the respective optimum levels. Each model is weighted and adjusted for age, sex, daily smoking, household income, marital status, education levels, accelerometer wear time, season, income, body mass index, self-perceived general stress and selfperceived mental health.

\section{REFERENCES}

1. Fink G. Stress: Concepts, Definition and History. In: Reference Module in Neuroscience and Biobehavioral Psychology. Elsevier; 2017:1-9.

2. Lazarus RS, Folkman S. Stress, Appraisal, and Coping. Springer Publishing Company; 1984. 460 p.

3. Juster RP, McEwen BS \& Lupien SJ. Allostatic load biomarkers of chronic stress and impact on health and cognition. Neurosci. Biobehav. Rev. 2010;35:2-16.

4. Selye H. Stress and physical activity. McGill Journal of Education. 1976

5. Bergmann N, Gyntelberg F, Faber J. The appraisal of chronic stress and the development of the metabolic syndrome: a systematic review of prospective cohort studies. Endocr Connect. 2014;3:55-80.

6. Justice NJ. The relationship between stress and Alzheimer's disease. Neurobiol Stress. 2018;8:12733.

7. Menard C, Pfau ML, Hodes GE, Kana V, Wang VX, Bouchard S, et al. Social stress induces 
medRxiv preprint doi: https://doi.org/10.1101/2020.05.11.20097931; this version posted May 14, 2020. The copyright holder for this preprint (which was not certified by peer review) is the author/funder, who has granted medRxiv a license to display the preprint in perpetuity. All rights reserved. No reuse allowed without permission.

neurovascular pathology promoting depression. Nat Neurosci. 2017;20:1752-60.

8. Crompton S. What's stressing the stressed? Main sources of stress among workers. Can Soc Trends Stat Can. 2011;11-008ロX.

9. American Psychological Association. Stress in America: Stress and Current Events. 2019. (Stress in America $^{\mathrm{TM}}$ Survey).

10. Maslach C \& Leiter MP. Understanding the burnout experience: recent research and its implications for psychiatry. World Psychiatry. 2016;15:103-111.

11. World Health Organization. Burn-out an « occupational phenomenon »: International Classification of Diseases. 2019

12. Gerber $\mathrm{M}$ et al. More than a simple pastime? The potential of physical activity to moderate the relationship between occupational stress and burnout symptoms. Int. J. Stress Manag. 2020;27:5364.

13. Ginoux C, Isoard-Gautheur S, Sarrazin P. "Workplace Physical Activity Program” (WOPAP) study protocol: a four-arm randomized controlled trial on preventing burnout and promoting vigor. $B M C$ Public Health. 2019;19:289.

14. Portugal E, Portugal EMM, Cevada T, Monteiro-Junior RS, Guimarães TT, Rubini E da C, et al. Neuroscience of Exercise: From Neurobiology Mechanisms to Mental Health. Neuropsychobiology. 2013;68:1-14.

15. Noh J-W, Lee SA, Choi HJ, Hong JH, Kim MH, Kwon YD. Relationship between the intensity of physical activity and depressive symptoms among Korean adults: analysis of Korea Health Panel data. J Phys Ther Sci. 2015;27:1233-7.

16. Chu AHY, van Dam RM, Biddle SJH, Tan CS, Koh D, Müller-Riemenschneider F. Self-reported domain-specific and accelerometer-based physical activity and sedentary behaviour in relation to psychological distress among an urban Asian population. Int J Behav Nutr Phys Act. 2018;15:36.

17. White RL, Babic MJ, Parker PD, Lubans DR, Astell-Burt T, Lonsdale C. Domain-Specific Physical Activity and Mental Health: A Meta-analysis. Am J Prev Med. 2017;52:653-66. 
medRxiv preprint doi: https://doi.org/10.1101/2020.05.11.20097931; this version posted May 14, 2020. The copyright holder for this preprint (which was not certified by peer review) is the author/funder, who has granted medRxiv a license to display the preprint in perpetuity. All rights reserved. No reuse allowed without permission.

WORK-RELATED STRESS AND PHYSICAL ACTIVITY

18. Wiese CW, Kuykendall L, Tay L. Get active? A meta-analysis of leisure-time physical activity and subjective well-being. J Posit Psychol. 2018;13:57-66.

19. Tremblay MS, Connor Gorber S. Canadian health measures survey: brief overview. Can J Public Health. 2007;98:453-6.

20. Day B, Langlois R, Tremblay M, Knoppers B-M. Canadian Health Measures Survey: ethical, legal and social issues. Health Rep. 2007;18 Suppl:37-51.

21. Gravel R, Béland Y. The Canadian Community Health Survey: Mental Health and Well-Being: Can J Psychiatry. 2005.

22. Esliger DW, Probert A, Gorber SC, Bryan S, Laviolette M, Tremblay MS. Validity of the Actical Accelerometer Step-Count Function: Med Sci Sports Exerc. 2007;39:1200-4.

23. Colley RC, Tremblay MS. Moderate and vigorous physical activity intensity cut-points for the Actical accelerometer. J Sports Sci. 2011;29:783-9.

24. Colley R, Connor Gorber S, Tremblay MS. Quality control and data reduction procedures for accelerometry-derived measures of physical activity. Health Rep. 2010;21:63-9.

25. Bauman AE, Reis RS, Sallis JF, Wells JC, Loos RJ, Martin BW. Correlates of physical activity: why are some people physically active and others not? The Lancet. 2012;380(9838):258-71.

26. Wood SN. Generalized Additive Models: An Introduction with R. Boca Raton, FL: Chapman and Hall/CRC; 2006. 416 p.

27. Lumley T. Complex surveys: a guide to analysis using R. Hoboken, N.J: John Wiley \& Sons; 2010.

28. Haskell W, Lee I, Pate R, Powell K, Blair S, Franklin B, et al. Physical Activity and Public Health: Updated Recommendation for Adults From the American College of Sports Medicine and the American Heart Association. Circulation. 2007;116:1081-93.

29. Jetté M, Sidney K, Blümchen G. Metabolic equivalents (METS) in exercise testing, exercise prescription, and evaluation of functional capacity. Clin Cardiol. 1990;13:555-65.

30. World Health Organization. Physical Activity and Adults: Recommended levels of physical activity for adults aged 18-64 years. 2010. 58 p. 
medRxiv preprint doi: https://doi.org/10.1101/2020.05.11.20097931; this version posted May 14, 2020. The copyright holder for this preprint

(which was not certified by peer review) is the author/funder, who has granted medRxiv a license to display the preprint in perpetuity.

All rights reserved. No reuse allowed without permission.

WORK-RELATED STRESS AND PHYSICAL ACTIVITY

31. Bernard P, Doré I, Romain A-J, Hains-Monfette G, Kingsbury C, Sabiston C. Dose response association of objective physical activity with mental health in a representative national sample of adults: A cross-sectional study. PLoS ONE. 2018;13.

32. Kim YS, Park YS, Allegrante JP, Marks R, Ok H, Ok Cho K, et al. Relationship between physical activity and general mental health. Prev Med. 2012;55:458-63.

33. Houdmont J, Jachens L, Randall R, Hopson S, Nuttall S, Pamia S. What Does a Single-Item Measure of Job Stressfulness Assess? Int J Environ Res Public Health. 2019;16:1480

34. Le Fevre M, Matheny J, Kolt GS. Eustress, distress, and interpretation in occupational stress. $J$ Manag Psychol. 2003;18:726-44.

35. McGowan J, Gardner G, Fletcher R. Positive and negative affective outcomes of occupational stress. N Z J Psychol. 2006;:92-98.

36. Lazarus RS. From Psychological Stress to the Emotions: A History of Changing Outlooks. Annu Rev Psychol. 1993;44:1-22.

37. Nagy T. Psychophysiological responses to distress and eustress. PhD Dissertation. Budapest, Hungary: Eötvös Loránd University; 2015. 127 p.

38. Schuch FB, Vancampfort D, Firth J, Rosenbaum S, Ward PB, Silva ES, et al. Physical Activity and Incident Depression: A Meta-Analysis of Prospective Cohort Studies. Am J Psychiatry. 2018;175:631-48.

39. Russo F, Williamson J. Interpreting Causality in the Health Sciences. Int Stud Philos Sci. 2007;21:157-70.

40. Sheeran P, Klein WMP, Rothman AJ. Health Behavior Change: Moving from Observation to Intervention. Annu Rev Psychol. 2017;68:573-600. 
